\title{
Couvade Syndrome and Health Status of The First Trimester of Primigravida
}

\author{
Tutu April Ariani \\ Departement of Nursing, Faculty of Health Sciences, University of Muhammadiyah Malang, \\ Indonesia \\ Jalan Bendungan Sutami 188A, Kota Malang, 65145 \\ Corresponding author: tutuapril11@gmail.com, tutuaprilariani@umm.ac.id
}

\begin{abstract}
Background: The Couvade Syndrome refers to physichal symptoms of varying intensity and severity experienced by expectant father. Many husbands who experience physical symptoms during pregnancy of the partner. This situation sometimes referred as Couvade Syndrome (Fathering). Anxiety of the husband when facingprimigravida wife in the first trimester with emesis gravidarum varies greatly from mild anxiety to panic. Objective: The aim was to determine the relationship between Couvade Syndromeof the husband and the incident of emesis gravidarumin primigravida wife in the first trimester. Method: This study used cross sectional approach. Data collection of Couvade Syndrome by measuring the anxiety level of husbands was using DASS questionnaires, while emesis gravidarum used a questionnaire based on the frequency of occurrence. Data was analyzed using the Spearman Rank analysis (significant level of $\alpha=0.05, p$ value $<\alpha)$ using a significant level. Result: Based on cross-tabulation between the occurrence of emesis gravidarum with husband anxiety level indicates the incidence of emesis gravidarum in moderate and severe level as many as 10 people (41.7\%) and the most dominant anxiety level of the husband that was moderate anxiety levels as many as 7 people (29.2\%). Result of Spearman Ranktest concluded that $\rho$ value $=0.03>\alpha=0.05$ (5\%). Conclusion: Husband anxiety when facing his wife with emesis gravidarum vary from no anxiety to panic, in this study the respond of husband anxiety when facing his wife with emesis gravidarum is in the moderate level.
\end{abstract}

Keywords: Couvade Syndrome, Husband Anxiety Levels, The Incidence Of Emesis Gravidarum.

\section{INTRODUCTION}

In last decade, interest in fatherhood has increased. It is known that pregnancy can have a profound physical, psychological and social impact on the expectant father. The Couvade Syndrome refers to physichal symptoms of varying intensity and severity experienced by expectant father. The Father has a new emerging role in pregnancy and childbirth. The male can be affected by the pregnancy although he undergoes a series of emotional and physical changes througtout the pregnancy. The progress and outcome of the pregnancy are not dependent on his presence and fatherhood is essentially a social invention (Dixon, 1978; Tudiver, 1981). In addition, resesarch result by Laplante (1991) is the pregnancy produced slight changes in the social and family activities of many of the fathers. A deterioration in their relationship with their spouse reported almost 33\%, generaly showed to increased sensitivity. Although $10 \%$ noted an improvement. 
When the wife suffered distress in pregnancy will affect the husband, because the husband is the closest person to his wife. During the pregnancy, wife requires more attention from the husband. The husband must help and assist pregnant wife infacing the complaints of pregancyin order that wife does not feel alone because continuing wife anxiety cause decreased appetite, physical weakness, and excessive nausea and vomiting. When doing antenatal care (first trimester) pregnant women want to complain the dizziness, excessive sweating, aches, and sometimes the husband missesthe moment when wife is doing an antenatal medical examination at the hospital (Sawitri \& Sudaryanto, 2008).

Anxiety of the husbandin facing primigravida wife in the first trimester withemesis gravidarum (nausea and vomiting) can be caused by lack of knowledge or information about emesis gravidarum, feel anxious when his wife nausea and vomiting is sustained (Sawitri \& Sudaryanto, 2008).

Continuous husband anxiety will have an impact on his wife, this can happen because the husband was too busy thinking about something bad will happen to his wife if nausea and vomiting constantly, so that the husband does not care about wife's pregnancy complaints other than nausea and vomiting. Danger will happen to the wife if the husband experiencing excessive anxiety, the wife likely will also experience anxiety even to stress (Octaviadon, 2011).

Many husbands experience physical symptoms during pregnancy of the partner. This situation is sometimes referred to as Couvade Syndrome (Fathering). In the study of Arthur Brenan (2010) in Australia about the incident of Couvade Syndrome in Australia that the shown symptoms include, weight gain, bloating nausea, vomiting, backache, toothache, loss of appetite, or abdominal cramps, headache, irritability, malaise and leg cramps are reported by future fathers too. Spouse restlessnessduring pregnancy is symptoms that reflect sympathy and identification with the pregnant woman, or perhaps reflecting worries and anxiety (Tudiver, 1981; Sponer, 1988; Ziegler et al, 2006; Brenann et al, 2007; Kazmierzak et al, 2013). Sympathetic pregnancy symptoms in men are referred to as 'couvade' indicating that men share some oftheir mate's pregnancy symptoms (Ziegler et al, 2006).

Couvade Syndrome is the best examined from the anthropology perpsective. Murphy (1992) writes about two types of the Couvade phenomenon: the ritual and modern. The ritual form was practiced early as the Greece ancient, and still found among so-called primitive societeies. The modern type refers to pregnancy-like symptoms which are observed amongst the partners of pregnant women. Munroe et al (1973), Broude (1988) distinguish two forms of the Couvade Syndrome, namely:1) classical or extreme and 2) magio-religius. In the classic form, the father enacts a childbirth sc ene, imitating symptoms experienced by the mother, also in labour. Munroe et al also found in their cross-sectional studies, the most frequenly observed form is the magio-religious one, which is assosiated with a spesific of prohitions for male behaviour such as a ban on hunting or eating specific foods. At the same time, on an unconsious level, the man is to go back to an identification with woman.

Nausea and vomiting is a common thing experienced by women in early pregnancy. Pregnant women experience nausea and vomiting (retching) and termed withEmesis gravidarum mostly in the first trimester, between 6 and 12 weeks, but it can continue until 20 weeks and lasts settle after this time in more than $20 \%$ of women (Matthews, et al ,2014; Mendoza and Amsler, 2017). 
Vomiting with more than ten times daily or continuous nausea which occurred during the last 20 weeks of pregnancy will continue to be hyperemesis gravidarum so the mother's body becomes weak, pale face, and frequency of urination decreased dramatically. Nausea and excessive vomiting also causes decreased body fluid and hemoconcentrationthat slows blood circulation so that it can affect fetal development. The first trimester is the phase of fetal organs formed (Hidayati, 2009).

Besides maternal physiological adaptations, various psychological stimulus can also be an emotional factor that causes the symptoms of nausea and vomiting became worse. Type of psychological stimulus in pregnant women is emotional distress. Psychological stress condition that can occur due to lack of support from her husband, causing mothers at first to adapt to the increase in hormones do not experience nausea and vomiting will experience these events.

Support can be given by the husband is give calm to the mother, accompanyto antenatal care, meet the desires for cravings, reminding to eat iron tablets, help in performing household activities and give a light massage when mothers feel tired, little things that the husband's do have meaning in improve the psychological health of a better direction. The support given by the husband is expected to help mothers pass the pregnancy by feeling good and without depression. The husband must continue to provide support to the wife in the pregnancy even though the husband is also sometimes experience physical symptoms during pregnancy of wife (Jhaquin, 2010).

Preliminary studies were conducted on October 6, 2015, in the area of Public health care of Singosari. By conducting interviews with the clinic, obtained that woman who experience nausea and vomiting usually were not recorded in the check out book, the clinic also just taking care of the pregnant women with hyperemesis gravidarum only. According to the results of interviews with six husbands when doing antenatal care at Singosari health center, showed that 4 of 6 husband felt anxious while she was experiencing nausea and vomiting, and while the two husbands states that did not experience anxiety because it is considered the norm in the early pregnancy if experiencing nausea and vomiting. While on 4 husband when asked about the treatment of nausea and vomiting of his wife when the husband replied by giving food so the stomach does not empty and buy his wife's favorite food. In 2 other husbands husband actually told his wife to sleep and do activities in order the nausea and vomiting are not felt again. It can be concluded that the husband will also feel anxiety when wives who experienced emesis gravidarum in the first pregnancy.

Based on data from the above background that researchers are interested to see whether the husband feel anxiety of the wife when experiencing nausea and vomiting (emesis gravidarum). If the view of the characteristics of the wife in a very excessive vomiting cause the husband may feel anxious, so that husband anxiety can be seen when accompanied the antenatal care, so the husband's role is very important.

\section{METHOD}

The population in this study were all expectant father who has a primigravida pregnant wife at the area of Public health care of Singosari as much as 78 expectant father. This study was implementing the inclusion criteria for the respondents, namely: Husband who had first trimester pregnant wife, a husband who has a wife who pregnant for the first time (primigravida), a wife who was having emesis gravidarum, willing to become respondents. Sampling techniques used in this study was quota sampling. 
This type of research is correlational analysis with cross-sectional approach. In this study, researchers wanted to determine the relationship of Couvade Syndrome of husbands and the incident of emesis gravidarum in the first timester primigravid women. The instrument in this study was a questionnaire. Couvade Syndrome of the husband that experienced anxiety was measured using a GAD (Generalized Anxiety Disorder) anxiety questionnaire, amounting to 10 questions adapted from the journal of the American Psychiatric Association in 2013. The validity test results obtained by researchers began $p$ $<0.37$ to $\mathrm{p}<1.00$. Reliability shown by these questionnaire is $\alpha=0.898$ (using Cronbach Alpha measurement). While emesis gravidarum using structured questions as many as 7 questions and the validity of the test results $\mathrm{p}<0.39$ to $\mathrm{p}<1.00$, with reliability according to Cronbach Alpha worth $\alpha=0.884$.

Both variables included in this study using ordinal data scale. Couvade Syndrome distinguished by five levels, namely: there is no anxiety, mild, moderate, severe and panic. On the other hand,Emesis gravidarum is distinguished from the frequency of occurrence as follows: mild, moderate and severe. Therefore, to answer the correlation between two variables, then used a statistical test of Spearmen Rank (Rho)with a significance level $\rho$ $<0.05$, which signifies acceptance of this research hypothesis. Analysis of the data in this study using SPSS 16 software program.

\section{RESULT AND DISCUSSION}

Table 1 The frequency distribution of respondents by age (in Public health care of Singosari, January 31 to February 14, 2016)

\begin{tabular}{cccc}
\hline No & Age Groups Husband & Frequency & Percentage \\
\hline 1 & Late adolescents (17-25 years) & 7 & 29.1 \\
2 & Early adulthood (26-35 years) & 16 & 66.6 \\
3 & Late Adulthood (36-45 years) & 1 & 4.1 \\
\hline & TOTAL & $\mathbf{2 4}$ & $\mathbf{1 0 0}$ \\
\hline
\end{tabular}

From Table 1 it can be seen from 24 husbands (respondents) of the first trimester primigravida mother, majority of respondents aged from early adult group (26-35 years), as many as 16 people (66.6\%). Age is one factor that can affect a person's anxiety. In this research note the data that more couples in early adulthood, which at this early adulthood phase sometimes many couple get new experience and untried having first married that age affects the occurrence of anxiety in a person.

Table 2 The frequency distribution of respondents by husband last education (in Public health care of Singosari, January 31 to February 14, 2016)

\begin{tabular}{cccc}
\hline No & Husband Education & Frequency & Percentage \\
\hline 1 & Primary school & 3 & 12.5 \\
2 & Junior high school & 7 & 29.1 \\
3 & Senior High School & 10 & 41.6 \\
4 & College & 4 & 16.6 \\
& TOTAL & $\mathbf{2 4}$ & $\mathbf{1 0 0}$ \\
\hline
\end{tabular}


From Table 2 can be seen that average majority of husband last education is high school as many as 10 people (41.6\%). High levels of education will extend a person's pointview and scope of the association, so that a higher level of education would facilitate a person to receive information about health. Likewise if the lower latest education then someone will narrow the pointview and easy to experience the anxiety due to less exposure to the information in the scope of life.

Table 3 The frequency distribution of respondents by husband's occupation (in Public health care of Singosari, January 31 to February 14, 2016)

\begin{tabular}{cccc}
\hline No & Husband Occupation & Frequency & Percentage \\
\hline 1 & Civil servants & 3 & 16.6 \\
2 & Private employees & 7 & 75 \\
3 & Entrepreneur & 10 & 8.3 \\
\hline & TOTAL & $\mathbf{2 4}$ & $\mathbf{1 0 0}$ \\
\hline
\end{tabular}

From Table 3. Known that majority of husband's occupation (the respondents) are private employees about 18 people (75\%). Private employees here is intended as a private sector company employees or laborers of the company, in this study the husband have more time outside, sometimes more than 8 hours work, so that the husband could not accompany his pregnant wife for 24 hours.

Table 4 Table of Emesis gravidarumFrequency

\begin{tabular}{ccc}
\hline No. & frequency & Percent \\
\hline Mild & 4 & $16.7 \%$ \\
Moderate & 10 & $41.7 \%$ \\
Severe & 10 & $41.7 \%$ \\
\hline Total & 24 & $100 \%$ \\
\hline
\end{tabular}

Based on Table 4 shows that the first trimester primigravida mothers were experiencing moderate level of emesis gravidarum as many as 10 people $(41.7 \%)$, and the severe level of 10 people $(41.7 \%)$. The incidence of emesis gravidarum have occurred due to various factors many of which can also occur because the emotions of the wife unstable due to possible lack of attention to her husband's busy working outside the house.

Identify the level of anxiety ofthe husband.

Nausea and vomiting is one of the earliest symptoms, the most common and cause stress associated with pregnancy (Tiran, 2007). For pregnant women, nausea and vomiting are often overlooked because it is considered as a normal consequence of early pregnancy without knowing the great impact that can caused. Nausea and vomiting are usually experienced by mothers during the first trimester. The first trimester pregnancies with a gestational age between 0-12 weeks (Vivian, 2011). The average age of the pregnancy of respondents is around 4-12 weeks.

Physiologically, the nausea caused by increased estrogen levels in the blood thereby affecting the digestive system. Yet nausea and vomiting that occur continuously can lead to dehydration, hyponatremia, hypochloremic, and a decrease in urine chloride 
(Yuni, 2009). Hypokalemia can occur due to excessive vomiting and excretion, further increasing the frequency of vomiting and damage the liver. Mucous membranes of the stomach and esophagus can be damaged, so it can lead to gastrointestinal bleeding. In addition to factors that increase estrogen levels, nausea and vomiting in pregnant women can be caused by psychological factors.

Results obtained from 24 respondents, the incidence of emesis gravidarumthere were moderate and severe categories is equal to each of 10 respondents (41.7\%). Emesis gravidarumsaid to be moderate if the nausea experienced by the wife is not more than 3 times a day and said to be heavy if vomit more than 3 times a day. It supports by the results of observation (participatory) to the wife and questionnaire distributed to the husband about the incidence of nausea and vomiting of his wife.

Table 5 Table of Anxiety Rate Frequency

\begin{tabular}{lll}
\hline Information & Frequency & Percentage \\
\hline No anxiety & 3 & $12.5 \%$ \\
Mild & 8 & $33.3 \%$ \\
Moderate & 7 & $29.2 \%$ \\
Severe & 4 & $16.7 \%$ \\
Panic & 2 & $8.3 \%$ \\
\hline
\end{tabular}

Based on Table 5 shows that husband anxiety when facing the wife who experience emesis gravidarum is in the mild to moderate level. This is because some husbands may lack information about new things so prone to feel anxiety.

The results showed that husband anxiety level when facing of his pregnant wife in the first trimester with emesis gravidarumis vary. The number of respondents in this study were 24 respondents and the majority of respondents experiencing mild anxiety, in this study said mild anxiety if the husbands were still able to anticipate the anxiety that occur while seeing his wife who experience nausea and vomiting as many as 8 respondents (33.3\%), and minority of respondents have panic anxiety as many as 2 respondents $(8.3 \%)$. Husband anxiety level can be known based on the characteristics of the husband, where husband characteristic include age, education level and occupation.

Age is one factor that can influence the occurrence of anxiety in a person, it is in accordance with the opinion of Miraswati (2006) which says that generally the anxiety of a person develops in adolescence and early adulthood, this condition can become frantic in their late teens to their 30s. The anxiety that arise due to aging somewhat related to past experiences the same thing or even a new experience that has not previously been experienced. The average age of the respondents in the age range 26-35 years. Besides the age factor of anxiety can be seen also through the educational level of a person.

Furthermore, education is a major factor in shaping the human person. Education plays an important role in shaping the human person is good or bad according to the size of the normative. Education is a supporting factor that plays an important role in all sectors of life, because the quality of life of a nation very closely with education (Karsidi, 2005) .From the results of research there are two respondents with secondary education level, it is known that a person's education level will affect a person's level of anxiety as more higher education will be easier to catch or receive information as well as mindset will grow when getting a new experience. It is supported by the results of studies showing that these respondents experienced a panic anxiety level. The resulting data were obtained from 
questionnaires of question number 1 and 2 were expressed about the feel frightened when he saw his wife nausea and vomiting and feeling anxious and nervous when facing his wife's nausea and vomiting.

Another factor that anxiety can also be seen from the characteristics of respondents by respondent's occupation. Majority of the husband's occupation is private employees as much as 18 respondents, it is known that the work be one of the factors that may affect the anxiety of a husband who has a the first trimester primigravida pregnant wife with emesis gravidarum. Husband have more work outside the house becomes idle in caring his pregnant wife. It is also supported by the study (Haafiz, 2007) states that the factor which cause husband's role become unprepared is work. Husband have more time outside the house so the husband sometimes skipped wife complaint about her pregnancy. Most husbands would work from early morning until late afternoon, sometimes their working hours until evening. It can make the husband think of anything bad will happen to her when he was not at home. This negative thinking that can lead to anxiety to her husband when he left his pregnant wife

Table 6 Crosstabs of Spearman Ranktest in Emesis gravidarum and Anxiety Levels

\begin{tabular}{|c|c|c|c|c|c|c|c|c|}
\hline & & & \multicolumn{5}{|c|}{ Anxiety level } & \multirow[t]{2}{*}{ Total } \\
\hline & & & No anxiety & Mild & Moderate & Severe & Panic & \\
\hline Emesis & Mild & Count \% & 2 & 1 & 1 & 0 & 0 & 4 \\
\hline \multirow[t]{5}{*}{ Gravidarum } & & of Total & $50 \%$ & $25 \%$ & $25 \%$ & $0 \%$ & $0 \%$ & $100 \%$ \\
\hline & Moderate & Count $\%$ & 1 & 6 & 3 & 0 & o & 10 \\
\hline & & of Total & $10 \%$ & $60 \%$ & $30 \%$ & $0 \%$ & $0 \%$ & $100 \%$ \\
\hline & Severe & Count $\%$ & o & 1 & 3 & 4 & 2 & 10 \\
\hline & & of Total & $0 \%$ & $10 \%$ & $30 \%$ & $40 \%$ & $20 \%$ & $100 \%$ \\
\hline \multirow[t]{2}{*}{ Total } & & Count $\%$ & 3 & 8 & 4 & 7 & 2 & 24 \\
\hline & & of Total & $12,5 \%$ & $33,3 \%$ & $29,2 \%$ & $29,2 \%$ & $8,3 \%$ & $100,0 \%$ \\
\hline
\end{tabular}

Table 6 explained that the results of cross tabulations on data analysis for the husband who has a wife experiencing mild anxiety as much as 8 (33.3\%) of people, and for the incidence of moderate emesis gravidarum of the first trimester primigravida women was $10(41,7 \%)$ and severe level as much as $10(41.7 \%)$ people. It can be concluded that the incidence of emesis gravidarum correlated with anxiety in different husband anxiety level.

Table 7 The result of Spearman Rank Test

\begin{tabular}{|c|c|c|c|c|}
\hline & & Emesis gravidarum & Anxiety level & $\mathrm{P}<0.05$ \\
\hline \multirow[t]{4}{*}{ Emesis gravidarum } & Correlation & 1,000 & .583 & \multirow[t]{4}{*}{0,003} \\
\hline & Coefficient & & & \\
\hline & Sig. (2-tailed) & , & .003 & \\
\hline & $\mathrm{N}$ & 24 & 24 & \\
\hline \multirow[t]{4}{*}{ Anxiety level } & Correlation & .583 & 1,000 & \multirow[t]{4}{*}{0,003} \\
\hline & Coefficient & & & \\
\hline & Sig. (2-tailed) & .003 & , & \\
\hline & $\mathrm{N}$ & 24 & 24 & \\
\hline
\end{tabular}


The result of Spearman Rank Test above can be concluded that value of $\rho=0.03>$ $\alpha=0.05(5 \%)$. The hypothesis the researchers received, so it can be concluded that there is a relationship between theincidenceof emesis gravidarum in the first trimester pregnant women with the husband anxiety level in the Public health care of Singosari.

Couvade Syndrome has been linked with male empathic responses to female partner pregnancy/ labour signs (Morse et al, 1998). Hoffman ML (Hoffman, 2003) acknowledge the emotional andcognitive components of empathy, they believe that physical side of empathizing cannot be ommited. As empathy is commonly defined as sharing emotions (usually negative) with another person. They define such physical responses to others' distress as compathy, an example of which is Couvade Syndrome. Couvade Syndrome become one of the signs of spouse's deep emotional engagement in pregnancy and childbirth. (Kazmierczak, 2013).

According to Stuart and Sundeen (2006), the level of anxiety characterized by physiological responses are mild, such as mild muscular tension, cognitive responses such as visual field extends passive awareness on the environment, and if seen from behavior and emotional resposes as the weakened voice, facial muscles relaxation, capable of performing ability or skill games automatically, there is a feeling of security and comfort.

\section{CONCLUSION}

It can be concluded that there is a relationship between Couvade Syndrome and the incidence of emesis gravidarum in pregnant women in the first trimester in the area of Public health care of Singosari. The results of this study found a significant relationship between the incidences of emesis gravidarum in the first trimester pregnant women with husband anxiety level in the area of Public health care of Singosari. So the incidence of emesis gravidarum in the first trimester pregnant women had to do with the anxiety level of the husband, if the incidence of emesis gravidarum is mild, then husband anxiety level can be resolved.

\section{REFERENCES}

Brenan, A., Ayers, S., S., Ahmed, H. \& Marshall-Lucette, S. (2007). A Critical Review Of The Couvade Syndrome: Pregnant Male. Journal of Reproductive and Infant Psychology. City University: London. 1-4

Broude GJ. (1988). Rethinking The Couvade: Cross-Cultural Evidence. American Anthropologist: 90(4):902-11

Dixon, AS. (1978). Paternal Participation-. Can. Fam. Pneed or Noveltyhysician. Vol: 34. Novenber. P: 1092-1098

Hafidz, E M. (2007). Correlation Between Spouse Role And Parent With Pregnant Woman Behaviour In Antenatal And Labor Services in Puskesmas Kecamatan Sedan Kabupaten Rembang. Jurnal Keperawatan Maternitas. Universitas Indonesia.2-3

Hoffman ML. 2003. Empathy and Development Implication for And Justice. Cambridge University Press. New York

Hidayati, R. (2009). Nursing Care In Physiological And Pathological Pregnant. Jakarta: Salemba Medika.

Jhaquin, A. (2010). Psycological For Midwifery. Yogyakarta: Nuha Medika.

Karsidi, R. (2005). Sosiologi Pendidikan Semarang: UNN Press dan LPP UNS. 
Kazmierczak, M. Kielbratowska, B. Pastwa-Wojciechowska, B. \& Preis, K. (2013). Couvade Syndrome Among Polish Expectant Father. Medical Science Monitor. Med Sci monit, 2013; 19: 132-138DOI: 10.12659/MSM.883791

Laplante, P. (1991). The Couvade Syndrome. Canadian Family Physician. Vol 37:163336,1660

Matthews,A. Dowswell, T. Haas, D. Doyle, M. \& O’Mathuna, D. (2014). Interventions for Nausea and Vomiting in Early Pregnancy. Cochrane Database Syst Rev; (9): CD007575. doi:10.1002/14651858.CD007575.pub2

Mendoza, E. \& Amsler, F. (2017). A randomized crossover trial on the effect of compression stockings on nausea and vomitingin early pregnancy. International Journal of Women's Health. 9 89-99. https://www.dovepress.com/terms.php.

Misrawati. (2006). Pengalaman dan Perilaku Suami Dalam Menunggu Istri Melahirkan Dengan Sectio Sesarea Tidak Direncanakan di Rumah Sakit Kota Jakarta. Jurnal Keperawatan Maternitas. Fakultas Ilmu Keperawatan Universitas Indonesia. 6-9

Morse JM. Mitcham C, \& Van der Steen Wj. (1998). Compathy or Physical Empaty: Implication for The Caregiver Relationshio. J Med Humanit: 19(1): 51-65

Munroe, RL. Munroe RH. \& Whiting JWM. (1973). The Couvade: a psychological analysis. Ethos: 1(1):30-73

Murphy RL. (1992). Couvade: The Pregnant Male. JPerinant Educ. 1(2): 13-18

Octaviadon, Della. (2011). Correlation between Spouse Support and Pregnant Woman towards Hyperemesis Gravidarum. Jurnal Kebidanan. Fakultas Kedokteran Universitas Sebelas Maret Surakarta.5-7

Sawitri, E dan Sudaryanto, A. (2008) Influencing Factors Anxiety before Caesar Surgery in Patient and Family in i RSUI Kustati Surakarta. 2-7

Spooner, GR. (1988). Fathering. Can. Fam. Physician. Vol: 34. P: 1755-1757

Stuart \& Sundeen. (2006). Handbook of Psychiatric Nursing. Jakarta: EGC.

Tiran. (2007). Pregnancy And That Problems. Jakarta: EGC

Tudiver, F. (1981). Fathers and Childbearing: New Dimensions. Vol: 27. 984-988

Vivian, D (2011). Pregnancy Caring For MidwiveryJakarta: Salemba Medika

Yuni, SE (2009). Pengaruh Peran Serta Suami Terhdap Tingkat Kecemasan Ibu Hamil Dalam Menghadapi Persalinan. Jurnal Kesehatan. Yogyakarta: Surya Medika.1-4

Ziegler, TE. Prudom, SL. Schiltz-Darken, NJ. Kuran. \& Snowdon, CT. (2006). Pregnancy Weight Gain: Marmoset and Tamarin Dads Show It Too. Biology Letters. Biol.Lett.(2006) 2, 181-183 doi:10.1098/rsbl.2005.0426 